\title{
HYDROGEN/HALOGEN ENERGY STORAGE SYSTEM: \\ SAFETY, PERFORMANCE, AND COST ASSESSMENT \\ FINAL REPORT
}

February 1979

\section{MASTER}

Prepared by

ORONZIO de NORA

Impianti Elettrochimici, S.p.A.

Via Bistolfi, 35, 20134 Milano, Italy

For the

ELECTROCHEMICAL TECHNOLOGY GROUP

ENERGY STORAGE AND CONVERSION DIVISION

DEPARTMENT OF ENERGY AND ENVIRONMENT

BROOKHAVEN NATIONAL LABORATORY ASSOCIATED UNIVERSITIES, INC.

UNDER CONTRACT NO. DE-AC02-76CHOOO16 WITH THE

UNITED STATES DEPARTMENT OF ENERGY 


\section{DISCLAIMER}

This report was prepared as an account of work sponsored by an agency of the United States Government. Neither the United States Government nor any agency Thereof, nor any of their employees, makes any warranty, express or implied, or assumes any legal liability or responsibility for the accuracy, completeness, or usefulness of any information, apparatus, product, or process disclosed, or represents that its use would not infringe privately owned rights. Reference herein to any specific commercial product, process, or service by trade name, trademark, manufacturer, or otherwise does not necessarily constitute or imply its endorsement, recommendation, or favoring by the United States Government or any agency thereof. The views and opinions of authors expressed herein do not necessarily state or reflect those of the United States Government or any agency thereof. 


\section{DISCLAIMER}

Portions of this document may be illegible in electronic image products. Images are produced from the best available original document. 
BNL 51070

UC-94c

(Energy Storage-Electrochemical -

TID-4500)

\section{HYDROGEN/HALOGEN ENERGY STORAGE SYSTEM: SAFETY, PERFORMANCE, AND COST ASSESSMENT}

\section{FINAL REPORT}

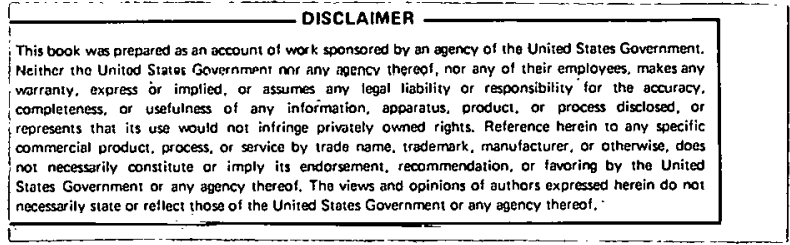

February 1979

\section{Prepared by}

P.M. Spaziante, G.C. Sioli, R. Trotta

Project Manager: A. Perego

ORONZIO de NORA

Impianti Elettrochimici, S.p.A.

Via Bistolfi, 35, 20134 Milano, Italy

BNL Contract No. 451857-S

ODN Job No. 018BNL

For the

ELECTROCHEMICAL TECHNOLOGY GROUP

ENERGY STORAGE - AND CONVERSION DIVISION DEPARTMENT OF ENERGY AND ENVIRONMENT

\section{BROOKHAVEN. NATIONAL LABORATORY UPTON; NEW YORK 11973}




\section{DISCLAIMER}

This book wan preparcd as an account if wink spunsireil hy an agency of the Uthited States Government. Ncithcr thc United States Guvernment nor any agency thereof, nor any of their employees, makes any warranty, cxpress or impilied, un assumes any legal liability or responsibility for the accuracy, completeness, or usefulness of any information, apparatus, product, or process disclosed, or represents that its use would

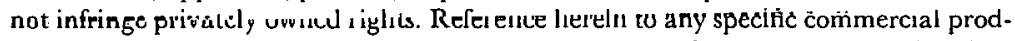
uct, process, or service by trade name, trademark, manufacturer, or ntherwice, dees not hécessarily constıtute or imply its endorsement, recommendation, or favoring by the United States Government or any agency thereof. The views and opinions of authors expressed herein do not necessarily state or reflect those of the United States Government or any agency thereof.

Printed in the United Statcs of $\Lambda$ merica

Available from

National Technical Information Service

U.S. Department of Commerce

5285 Port Royal Road

Springfield, VA 22161

Price: Printed Copy $\$ 4.50 ;$ Microfiche $\$ 8.00$

$A 03$

AOI 


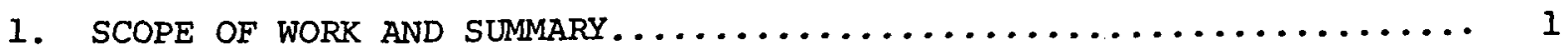

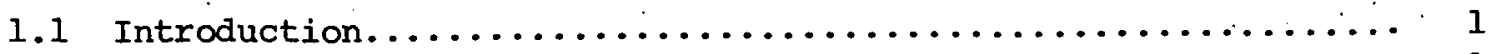

1.2 Summary ...................................... 1

2. TECHNICAL INPUTS FOR PIANT DESIGN AND SAFETY ASSESSMENT........... 4

2.1 Safety Assessment.............................. 4

2.2 Plant Design................................. 5

3. PROCESS DESIGN BASIS............................

$3 . \mathrm{I} \mathrm{H}_{2} / \mathrm{Cl}_{2}$ system.................................. 6

3.1.1 Section 100: Chlorine/Hydrochloric Acid Storage and

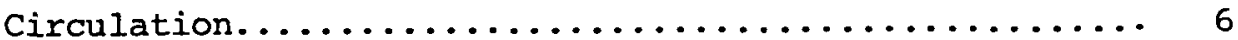

3.1.2 Section 200: Hydrogen Cleanup and Storage........... 6

3.1.3 Section 1000: Let-down Facilities................. 7

3.1.4 Section 4800: Blow-down Facilities................ 7

3.1.5 Section 3500: Cooling Water Production and Distribution 7

3.1.6 Section 5700: Hot water Generation and Distribution... 7

$3.2 \mathrm{H}_{2} / \mathrm{Br}_{2}$ system.................................

4. PLANT CONFIGURATION. .............................

4.1 Introduction. .............................. 8

4.2 Plant Description............................... 11

4.2.1 Section 100 - 2-MW/20-MWh $\mathrm{H}_{2} / \mathrm{Cl}_{2}$ Halogen Cell Module... 12

4.2.1.1 $\mathrm{H}_{2} / \mathrm{Cl}_{2}$ System (see P\&I No. 018-P-API-101-C) ... 12

$4.2 .1 .2 \mathrm{H}_{2} / \mathrm{Br}_{2}$ system....................... 14

4.2.2 Section 200 - Hydrogen Cleanup and storage System ' (see

P\&I No. 018-P-API-201/202) ..................... 14

4.2.3 Section 1000 - Module's Let-down (see P\&I No. 018-P-API-

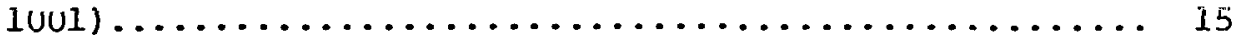

4.2.4 Section 4800 - Blow-down Facilities (P\&I No. 018-P-APU-

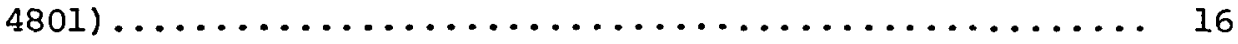

4.2.5 Other Sections (see flow-sheet No. 018-P-AFS-002-E)... 16

5. SAFETY FEATURES. ................................ 17

5.1 Impact of Site Location.......................... 17

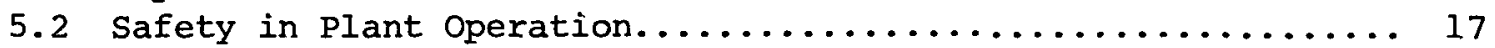

5.2 .1 Safety under Normal operating Conditions........... 1\%

5.2 .2 Safety During Emergencies..................... 19

5.3 Emission Limits............................... 21 
CONTENTS (cont'd.)

Page

6. PARASITIC POWER ANALYSIS AND OVERALL ELECTRIC EFFICIENCY........ 21

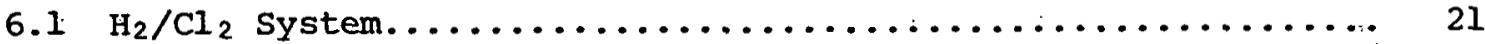

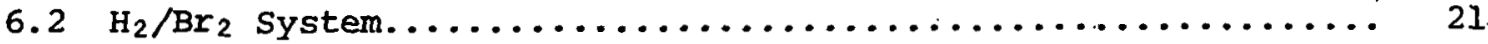

7. PLANT COST ESTIMATE............................. 24

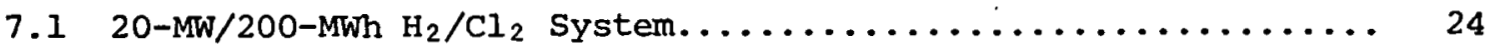

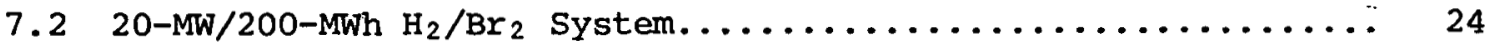

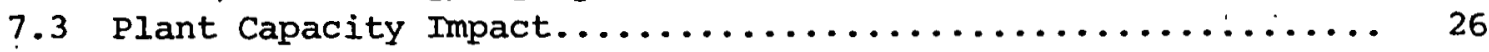

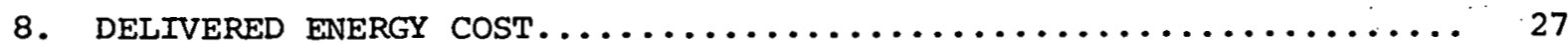

9. ACKNOWLEDGMENTS ............................ 29 
1. SCOPE OF WORK AND SUMMARY

\subsection{Introduction}

The aim of this work was to make realistic assessments of the safety, performance, and installation costs of an electrochemically regenerative $\mathrm{H}_{2} / \mathrm{Cl}_{2}$ energy storage system based on detailed engineering designs of plant configurations. Extensive laboratory tests in FY 1976, 1977, and 1978 provided the needed theoretical and experimental data for this study. The effectiveness of this scheme of energy storage required practical confirmation. In this assessment particular care was taken to list and include all the secondary units needed for plant operation.

In this task, Oronzio de Nora (ODN) had three goals: (i) a clear statement of the complexity of the installation; (ii) a complete check of relevant safety regulations; and (iii) delineation of the state of the art of applicable common industrial technology (i.e., technology now used in similar installations, not projected technical solutions).

\subsection{Summary}

ODN carried out a complete study of a 20-MW/200-MWh $\mathrm{H}_{2} / \mathrm{Cl}_{2}$ energy storage system with emphasis on the safety and cost aspects. $\mathrm{A} \mathrm{H}_{2} / \mathrm{Br}_{2}$ system was also considered for comparison with the base case. The first step in the study was a detailed check of various safety regulations relevant to the fluids handled in such a plant. In many cases these regulations do not cover ali the problems associated with such an installation; ODN compensated for this by drawing on its wide experience in the chlor-alkali industry in designing the plant.

A $\mathrm{H}_{2} / \mathrm{Cl}_{2}$ plant was designed for safe operation under normal operating conditions and for maximum safety in an emergency. The plant was designed for isothermal operation at $71^{\circ} \mathrm{C}$, with chlorine stored along with $\mathrm{HCl}$ in glass-lined steel vessels, and hydrogen stored as a compressed gas at 600 psi, in steel vessels. The plant design features for safety under normal operation (see Figure 1) were as follows:

i. Selection of highly reliable equipuent.

ii. Use only of tried and tested equipment.

iii. A high safety factor, 50\% (rather than the usual 10\%), in the $\mathrm{Cl}_{2} / \mathrm{HCl}$ storage system.

iv. Minimal use of valves and flanges.

$v$. Use of valves of the fail-safe type.

vi. All purges and vents through a high efficiency waste disposal system.

vii. Computer monitoring of all operations. 


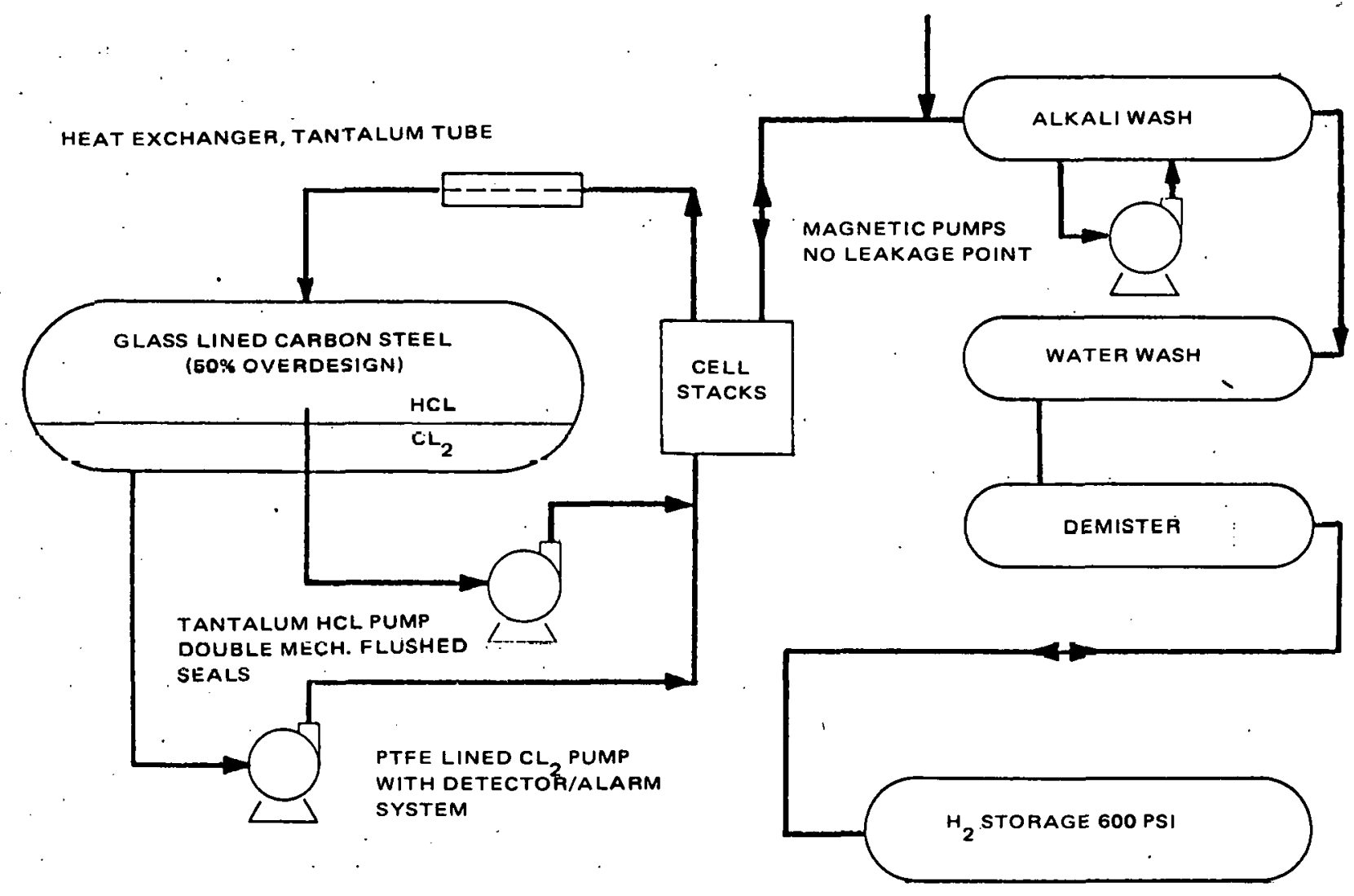

Figure 1. Plant Flow. Sheet

The principal design features for safety under emergency conditions were as follows:

i. Modularization of the cells and the $\mathrm{Cl}_{2} / \mathrm{HCl}$ storage, circulation, and heat-exchange systems into ten modules.

ii. Enclosure of each module in a building with slightly negative pressure, with air discharge through an alkali wash system.

iii. Incorporation of a monitor in the $\dot{C}_{2} / \mathrm{HCl}$ storage tanks to detect incipient failure of the qlass lining before it becomes a problem.

iv. Incorporation of interlocking systems to place a module on standby in an emergency while the remainder of the plant continues to operate.

v. Use of a let-down system permitting rapid transfer in liquid form of a module's contents to empty storage vessels. 
vi. An alkali scrub blow-down system that can neutralize the fluids from the let-down system to form a commercial solution of sodium hypochlorite.

vii. A compressed-air system and an an emergency diesel electric generator for carrying out the latter two operations in the event of simultaneous module failure and electric power failure.

The plant cost, parasitic loads, overall efficiency, and land requirements were determined for three site locations: an industrial site, a utility site, and a remote location. Plant costs were based on suppliers' quotations and on ODN file data and should be taken as very realistic estimates. Parasitic loads include energy losses for reactant circulation, hydrogen cleanup, and water cooling and heating for isothermal operation. Land requirements are dictated principally by safety and maintenance requirements. ODN attempted to determine delivered energy costs, but these are greatly affected by the assumptions made.

One of the most significant results of this study was confirmation of the idea that a high performance plant could be constructed with use only of equipment already available and tested on stream under analogous conditions. No new equipment need be designed, and the behavior of the materials is well known.

ODN concluded that it is not possible for the plant to operate unattended. Safety considerations necessitate at least 2 to 3 skilled operators per shift. This level of personnel would be excessive for normal operation but would be required in the event of an emergency. Note that in the chlor-alkali industry the common practice is to face chlorine emergencies under conditions such that control is in the hands of human operators, not left to automated devices.

Required land areas range from 4.3 acres for a utility site to 5.44 acres for an industrial site. The large land requirements and safety considerations preclude operation in a populated area such as a substation location.

Overall plant costs are only minimally affected by siting: $\$ 23.12$ million for the utility site and $\$ 23.69$ million for the industrial site. plant costs can be divided into those related (i) to power production and (ii) to energy storage capacity; for the base case these are $\$ 457.6 / \mathrm{kW}$ and $\$ 72.86 / \mathrm{kWh}$ respectively. The effect of increasing energy storage capacity on plant cost was evaluated for the 20-MW plant. Total cost per kWh dropped as energy storage capacity rose: from $\$ 118.5 / \mathrm{kWh}$ for a $200-\mathrm{MWh}$ plant to $\$ 75.6 / \mathrm{kWh}$ for an $800-\mathrm{MWh}$ plant.

With parasitic losses taken into account, the overall eletric-to-electric efficiency of the $\mathrm{H}_{2} / \mathrm{Cl}_{2}$ system is $66.6 \%$. Non-isothermal operation would increase this somewhat.

Delivered energy costs were determined with various assumptions on the cost of capital, electricity, fuel oil, and labor. They vary from 5.9 to 
$7.28 \mathrm{k} / \mathrm{kWh}$. for the industrial site and from 5.78 to $7.28 \mathrm{k} / \mathrm{kWh}$ for the utility site.

The studies of the $\mathrm{H}_{2} / \mathrm{Br}_{2}$ system were less accurate because the design basis is less well defined. Laboratory work is needed to obtain such basic parameters as $\mathrm{Br}_{2}$ solubility in $\mathrm{HBr}$ at various temperatures, and the cell resistance and thermal behavior require further characterization.

Bromine is more toxic than chlorine, but, because the system operates at much lower pressures (<50 psi), the cost of hydrogen/acid storage system is lower. The high solubility of $\mathrm{Br}_{2}$ in $\mathrm{HBr}$ eliminates the need for a separate halogen metering pump. Thus, even though the cost of hydrogen storage is somewhat higher, the overall plant cost for a 20-MW/200-MWh unit is lower: $\$ 20.5$ million. The high solubility of $\mathrm{Br}_{2}$ in $\mathrm{HBr}$ also reduces the parasitic pumping requirements so that the overall electric-to-electric efficiency is 69.83\%. On the whole, the $\mathrm{H}_{2} / \mathrm{Br}_{2}$ system looks attractive, but it requiree further characterization by laboratory tests. The knowledge of the $\mathrm{H}_{2} / \mathrm{Cl}_{2}$ system is such that it could be constructed at the present time.

Table 1 summarizes the costs and efficiencies for the $\mathrm{H}_{2} / \mathrm{Cl}_{2}$ and $\mathrm{H}_{2} / \mathrm{Br}_{2}$ systems.

Not only the $\mathrm{H}_{2} / \mathrm{Br}_{2}$ system, but also the $\mathrm{H}_{2} / \mathrm{Cl}_{2}$ system should be investigated further when more data are available. Non-isothermal operation should be considered. Designs for large plants ( $800 \mathrm{MWh}$ ) should be considered with a view to further reduction in storage costs.

\begin{tabular}{|c|c|c|}
\hline \multicolumn{3}{|c|}{$\begin{array}{l}\text { Hydrogen/Halogen Energy storage System } \\
\text { Costs dud Efficiency for a 20-MW/200-MWh Blant }\end{array}$} \\
\hline & Chlorine & Bromine \\
\hline Total costs & $\$ 23,720,000$ & $\$ 22,100,000$ \\
\hline \multicolumn{3}{|l|}{ Unit tusl's } \\
\hline per $\mathrm{kw}$ & 457.6 & 431.5 \\
\hline per kWh & 72.86 & 67.36 \\
\hline Efficiency (utility site) & $67 \%$ & 708 \\
\hline
\end{tabular}

2. TECHNICAL INPUTS FOR PLANT DESIGN AND SAFETY ASSESSMENT

2.1 Safety Assessment

National Fire Protection Association, National Fire Codes, Vol. 4: Standard for Gaseous Hydrogen System at Consumer sites. 
Compressed Gas Association, Inc., Standard for Gaseous Hydrogen System at Consumer Sites, Pamphlet G-5.1.

Compressed Gas Association, Pamphlet G-5: Hydrogen.

Association of Casualty and Surety Companies Pamphlet C-43: Chlorine.

Manufacturing Chemists Association, Inc., Chemical Safety Data Sheet SD-80: Chlorine.

Manufacturing Chemists Association, Inc., Chemical Safety Data Sheet SD-39: Hydrochloric Acid.

National Safety Council: Chlorine Data Sheet 207.

American Conference of Governmental Industrial Hygienists: Threshold Limit Values for Chemical substances in workroom Air.

Matheson Gas Products: Effects of Exposure to Toxic Gases (Hydrogen Halides).

I.N. Sax: Hazardous Industrial Chemicals (Bromine and Hydrobromic Acid).

Hazardous Chemicals Data: $\mathrm{H}_{2}, \mathrm{HCl}, \mathrm{HBr}, \mathrm{Br}_{2}$.

Manual of Hazardous Chemical Reactions: Bromine and Hydrobromic Acid.

Matheson Gas Products Pamphlet: Hydrogen Bromide.

National Safety Council: Bromine Data Sheet D-313.

Manufacturing Chemists Association, Inc., Chemical Safety Data Sheet SD-49: Bromine.

\subsection{Plairl Desigyis}

Bechtel Final Report, September 1977.

Energy Development Associates: Contract No. 386032-7 Final Report, September 1977.

BNL: $\mathrm{Cl}_{2}$ Hydrogen Energy Storage System, Annual Report 1977 (BNL-50924).

BNL and Clarkson College: An Electrochemically Regenerative $\mathrm{H}_{2} / \mathrm{Cl}_{2}$ Energy Storage System: A Study of Mass and Heat Balance, March 1978 (BNL-24500). 
Energy Development Associates, Report on Zinc-Chlorine Hydrate Batteries, March 1976.

J. MCBreen, Personal communication, August 9, 1978: $\mathrm{H}_{2} / \mathrm{Cl}_{2}$ Energy Storage Systems, Various inputs.

J. McBreen, Personal communication, September 27, 1978: $\mathrm{H}_{2} / \mathrm{Br} 2$ Cycle Material and Heat Balance.

\section{PROCESS DESIGN BASIS} below.

All the assumptions made for the design of the equipment are described

\section{$3.1 \mathrm{H}_{2} / \mathrm{Cl}_{2}$ System}

3.1.1 Section 100: Chlorine/Hydrochloric Acid storage and Circulation

ODN assumed an operating pressure of 400 psia for the $\mathrm{Cl}_{2} / \mathrm{HCl}$ storage $(\mathrm{V}-10 \mathrm{I} \mathrm{A} \div \mathrm{T}) . *$ The design pressure is 600 psig (see Bechtel Final Report). Cell operating temperature was fixed at $71^{\circ} \mathrm{C}\left(160^{\circ} \mathrm{F}\right)$, an average of the range indicated by Bechtel.

The design temperature is $100^{\circ} \mathrm{C}\left(212^{\circ} \mathrm{F}\right)$ with a reasonable allowance for the cell operating temperature. Chlorine flow rate in both charge and discharge cycles is that indicated by Bechtel. Chlorine addition (during discharge cycle) was fixed at $6500 \mathrm{lb} / \mathrm{hr}$ (Bechtel), but this can be adjusted if necessary (although not in a simple way) during a normal discharge cycle. The $\mathrm{HCl}$ circulation rate is fixed at $2000 \mathrm{gpm}$ as indicated by BNL.

ODN assumes that small chlorine entrainments into the HCl circulated through the cell (EL-101 $\mathrm{A} \div \mathrm{J}$ ) during the charge period do not affect the cell's efficiency and therefore ODN eliminates the HCl bypass line of the Bechtel design and passes the full stream through the settlers. This configuration reduces the number of pumps and eliminates the flow control loop.

\subsubsection{Section 200: Hydrogen Cleanup and Storage}

ODN assumes that the cell operating pressure is 600 psia during the charge cycle and 100 psia during discharge (Bechtel), and that the hydrogen leaves the cathode in equilibrium at $71^{\circ} \mathrm{C}\left(160^{\circ} \mathrm{F}\right)$ with a very weak acid solution (< $1 \mathrm{M})$. Both the $20 \%$ caustic soda and the water for the two washing towers will be changed from time to time on the basis of the liquid stream composition.

Storage of hydrogen as compressed gas was considered because Bechtel found it to be the most economical. ODN chose a lower-pressure storage system having a higher investment cost but lower parasitic power consumption.

\footnotetext{
* The numbers refer to the flow sheet diagrams which are on file at BNL.
} 


\subsubsection{Section 1000: Let-down Facilities}

The overall capacity of the let-down system was chosen to be about $132 \mathrm{~m}^{3}$ so that the vessels would not be filled to $>80 \%$ of their total diameter to allow ample leeway in the overall volume. Let-down vessels $(\mathrm{V}-1001 \mathrm{~A} \div \mathrm{C})$ have the same operating pressure and design conditions as those for $\mathrm{Cl}_{2} / \mathrm{HCl}$ storage. The system was designed to allow a maximum evacuation time of $15 \mathrm{~min}$.

\subsubsection{Section 4800: Blow-down Facilities}

This subunit serves to cleanup the electrolysis foreign gas and $\mathrm{Cl}_{2} / \mathrm{HCl}$ storage purge air. The system was designed to perform air purging of each module with the assumption that the air volume in each module is replaced once per hour and that this air is in equilibrium with a $35 \% \mathrm{HCl}$ solution.

Caustic soda is used to neutralize the $\mathrm{HCl}$ saturating the purge air, and excess $\mathrm{NaOH}$ provides a good driving force to the scrubber. The fresh. caustic soda holdup system was sized with sufficient capacity to carry out any operation after a 10-hr purge of the modules. The system is designed also to absorb all the chlorine in a module with production of $180 \mathrm{~g} / \mathrm{l}$ sodium hypochlorite solution in about $90 \mathrm{hr}$.

\subsubsection{Section 3500: Cooling Water Production and Distribution}

This unit was designed to run at partial load duxing the cycle's dead periods because a cooling towex cannot be continuously started up and shut down.

\subsubsection{Section 5700: Hot Water Generation and Distribution}

This unit is designed to lower the heat demand peak. The total heat required by the daily cycle is apportioned over $24 \mathrm{hr}$ by means of a heat accumulator.

\section{$3.2 \mathrm{H}_{2} / \mathrm{Br}_{2}$ System}

Conceptual differences in the use of a $\mathrm{H}_{2} / \mathrm{Br}_{2}$ cell arise only with respect to module design. All ODN hypothesis are based on the data provided by BNI (Table 2). The cell's feed rate is based on a bromine conversion of $20 \%$ and an overall cell efficiency of $75.2 \%$. Because of the high solubility of $\mathrm{Br}$ in $\mathrm{HBr}$ solution, it is assumed that the bromine dissolved in the feed during the cell's discharge period is always enough to provide the amount necessary for electricity production, and a bromine metering pump is not needed. 


\begin{tabular}{|c|c|c|c|}
\hline \multicolumn{4}{|c|}{$\begin{array}{c}\text { Table } 2 \\
\text { Characteristics of HBr Solutions at } 95^{\circ} \mathrm{C}\end{array}$} \\
\hline $\begin{array}{l}\text { HBr conc., } \\
\text { wt } 8\end{array}$ & $\begin{array}{l}\text { Density, } \\
\mathrm{kg} / 1\end{array}$ & $\begin{array}{l}\text { Bromine solubility, } \\
\text { moles } \mathrm{Br}_{2} / 1\end{array}$ & \\
\hline $\begin{array}{r}8 \\
10 \\
15 \\
20 \\
25 \\
30 \\
35\end{array}$ & $\begin{array}{l}1.035 \\
1.058 \\
1.116 \\
1.144 \\
1.195 \\
1.244 \\
1.320\end{array}$ & $\begin{array}{l}1.42 \\
2.62 \\
3.60 \\
5.00\end{array}$ & 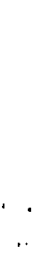 \\
\hline $\begin{array}{r}\text { Density data are } \\
\rho_{1}=0.9851 \\
\text { Bromine solubili } \\
\text { moles } \mathrm{Br}_{2} / 1\end{array}$ & $\begin{array}{l}\text { the follor } \\
+0.8358 \\
\text { crelated by } \\
.5672(8)\end{array}$ & $\begin{array}{l}\text { equation: } \\
3^{2} \text {. } \\
\text { following equation: } \\
95(8)^{2}+0.0055(8)^{3}\end{array}$ & \\
\hline
\end{tabular}

\section{PLANT CONFIGURATION}

\section{I Introduction}

In developing the plant layout, the goals were safety of operation, ease of construction and maintenance, and minimization of land area requirements. The schematic view of the basic plant (Figure 1) includes only items pertaining directly to the cell itself. All the units that should be assembled to operate the plant in the most general situation are listed in Annex 1* together with block diagram No. 018-P-ABD-001-E. The plant is complex because of the many auxiliary units required for normal and emergency operations. The plant layout was studied for both hydrogen/halogen systems in three different cases because site location deeply affects area requirements.

Case A. Industrial site. An area close to an electric power user, without any connection to utilities of an existing factory.

Case B. Utility site. An area close to an electric power producer, with connections to the utilities of a power station.

Case C. Remote site. An area far from any electrlc power producer or user, or any inhabited area, with no connection to existing utilities.

*All annexes and block diagrams are on file at BNL. 
All the differences between the various alternatives regarding environment, safety impact, utilities available at battery limits, and utilities located within battery limits are listed in Table 3 and block diagram No. $018-\mathrm{P}-\mathrm{ABD}-001 / 2 / 3$. The main differences are in plant complexity and therefore in area occupied; the remote site differs somewhat with respect to the degree of safety required. The land requirements for a 20-MW/200-MWh hydrogen/ chlorine plant with low pressure hydrogen storage are as follows:

\begin{tabular}{lc}
\multicolumn{1}{c}{ Site } & Area (acres) \\
\hline industrial & 5.44 \\
utility & 4.30 \\
remote & 5.44
\end{tabular}

These are the minimum areas practically achievable with common hydrogen storage systems. Another hydrogen storage concept that requires a larger area but has a lower investment cost was discarded because of its higher parasitic power consumption; Figures 2 and 3 provide a comparison of the areas required for the industrial site case with the two different methods of $\mathrm{H}_{2}$ storage.

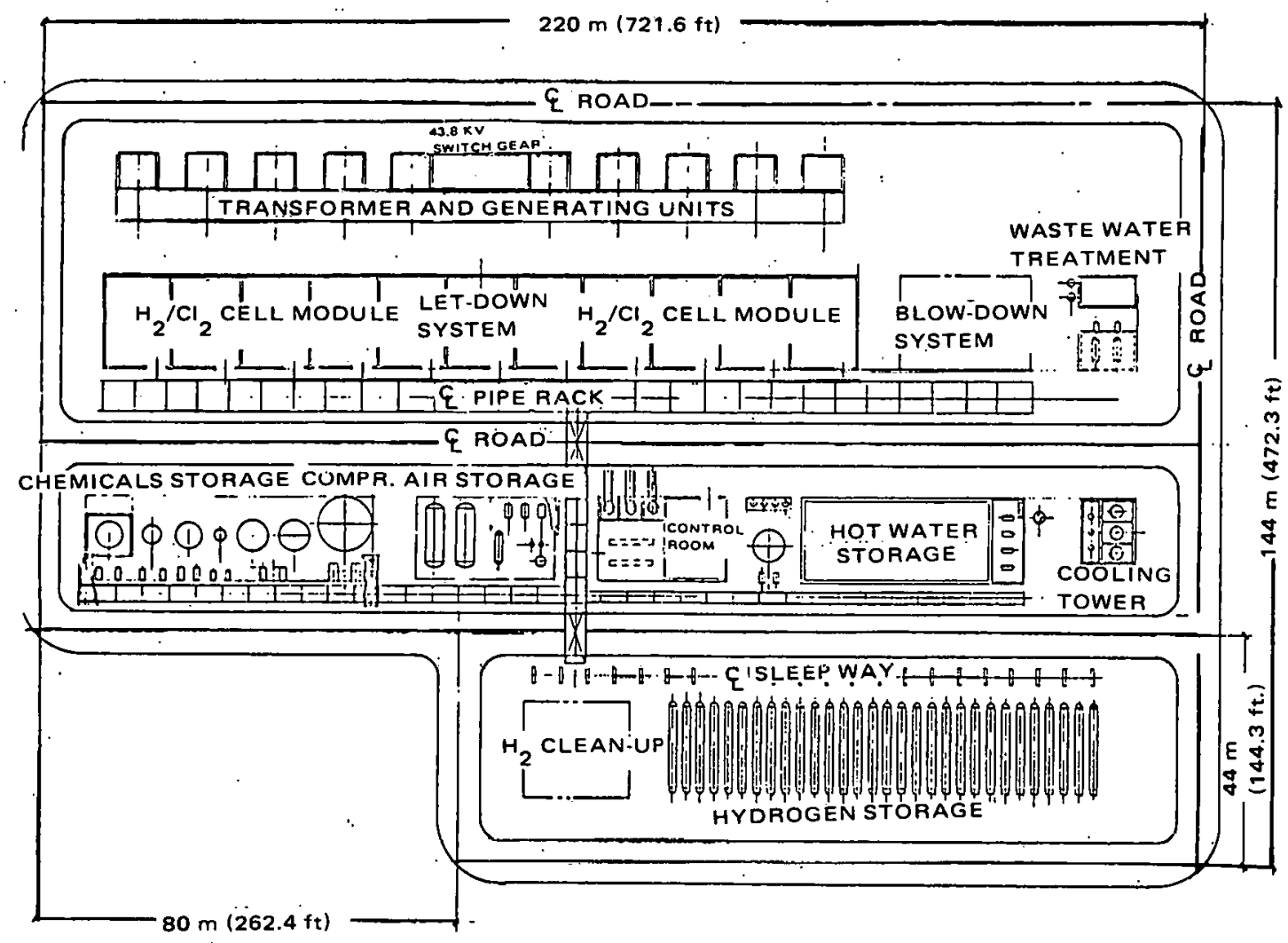

Figure 2. Industrial Site; High Pressure $\mathrm{H}_{2}$ Storage; Total Plant Area $=22,000 \mathrm{~m}^{2}(5.44$ acres $)$ 
Table 3

Comparison of sites: (A) Industrial, (B) Utility, (C) Femote

\begin{tabular}{|c|c|c|c|c|}
\hline & En:ironment & Safety & $\begin{array}{l}\text { Utilities available: } \\
\text { at bat=ery limits. }\end{array}$ & $\begin{array}{c}\text { Utilities unit located within } \\
\text { battery limits }\end{array}$ \\
\hline A. & $\begin{array}{l}\text { Industrial area. } \\
\text { Factories all } \\
\text { around. } \\
\text { Proximity of } \\
\text { workers at } \\
\text { other Ilants. }\end{array}$ & $\begin{array}{l}\text { Highest degree of } \\
\text { safety required. } \\
\text { Every type of safety } \\
\text { device desirable. } \\
\text { All equipment con- } \\
\text { taining } \mathrm{Cl}_{2} \text { should } \\
\text { be within a ven- } \\
\text { tilated building. }\end{array}$ & $\begin{array}{l}\text { Treated. water. } \\
\text { Fuel oil (tank car). } \\
\text { Electri= power. }\end{array}$ & $\begin{array}{l}\text { Softened water. } \\
\text { Cooling water and hot water. } \\
\text { Fuel oil storage. } \\
\text { Blanketing gas. } \\
\text { Fire-fighting water. } \\
\text { Wastewater treatment. } \\
\text { HCl and NaOH storage. } \\
\text { B-ow-down effluents storage. } \\
\text { E-ez-ric power network. } \\
\text { Control room. }\end{array}$ \\
\hline B. & $\begin{array}{l}\text { Nearby power } \\
\text { source. } \\
\text { Proximity of } \\
\text { workers at } \\
\text { other plants. }\end{array}$ & Same as far $A$. & $\begin{array}{l}\text { Cooling water. } \\
\text { Steam. } \\
\text { Compressed air } \\
\text { (medium pressure). } \\
\text { Instrument air. } \\
\text { Treated and fire- } \\
\text { fighting water. } \\
\text { Softened water. } \\
\text { Electric power. } \\
\text { Fuel oil (pipe). }\end{array}$ & $\begin{array}{l}\text { High pressure air. } \\
\text { Bianiceting gas. } \\
\text { Wast zwater treatment. } \\
\text { HCl and NaOH storage. } \\
\text { Blow-down effluents storage. } \\
\text { Electric power network. } \\
\text { Control room. }\end{array}$ \\
\hline c. & $\begin{array}{l}\text { Deserted area. } \\
\text { No factory or } \\
\text { house nearby. } \\
\text { No workers at } \\
\text { other plants } \\
\text { nearby. }\end{array}$ & $\begin{array}{l}\text { Lower degree of } \\
\text { safety recuired. } \\
\text { Equipment contain- } \\
\text { ing } \mathrm{Cl}_{2} \text { may be in } \\
\text { open air. }\end{array}$ & $\begin{array}{l}\text { Raw water. } \\
\text { Fuel oil (tank car). } \\
\text { Electric power. }\end{array}$ & $\begin{array}{l}\text { Same as for } A \text {. } \\
\text { Treated water. }\end{array}$ \\
\hline
\end{tabular}




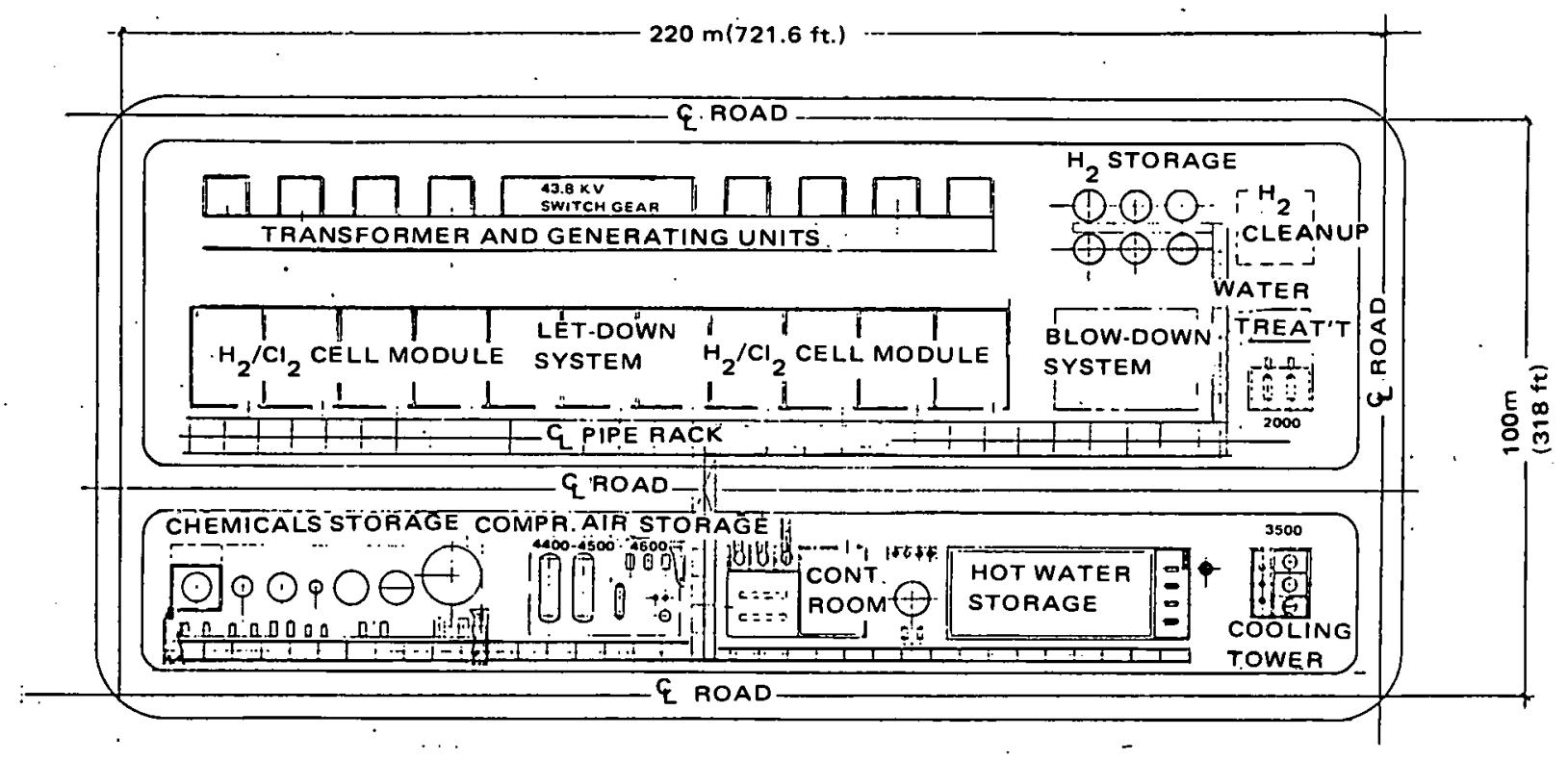

Figure 3. Industrial Site; Low Pressure $\mathrm{H}_{2}$ Storage; Total Plant Area $=22,000 \mathrm{~m}^{2}$ (5.44 acres)

The area requirements for the $\mathrm{H}_{2} / \mathrm{Br}_{2}$ system are somewhat larger because of the greater volume of chemicals stored; the increase $\sim 0.1$ acre for both the industrial and utility sites.

The distances between pieces of equipment and between various units are dictated by maintenance requirements and are the minimum consistent with safety regulations.

The list of the units and the plant layout give a good idea of the equipment that should be continuously checked to avoid misoperation problems. It is ODN's opinion that the plant cannot be left unattended even when instrumented for automatic monitoring.

\subsection{Plant Description}

The main unit of the plant is the hydrogen/halogen battery. To increase safety (as explained bclow) and to facilitate construction, it is divided into 2-MW/20-MWh modules, each independently operated. Safety considerations suggest that each module be installed in a closed building kept at slightly negative pressure by an alkali-scrubbed ventilation system.

Except for utilities, the only interconnections between the single modules and the rest of the plant are as follows: the hydrogen inlet-outlet line, the foreign gas venting to blow-down, and let-down lines. The purpose of the blow-down and let-down facilities is to maximize safety of operation. 
It is the opinion of ODN and also of BNL and Bechtel that one of the very few negative aspects of this method of energy storage is the extremely hazardous nature of the chemicals involved. Chlorine, bromine, $\mathrm{HCl}$, and $\mathrm{HBr}$ are very toxic, and hydrogen is explosive.

The purpose and operation of the main units are described in detail below. The safety regulations foreseen for each unit are described in section 5. The economics are cited below and discussed in sections 7 and 8 .

Emphasis is on the $\mathrm{H}_{2} / \mathrm{Cl}_{2}$ system because it has been more thoroughly investigated; the $\mathrm{H}_{2} / \mathrm{Br}_{2}$ system in described only in comparison with the base case. Annex 2 * contains all the equipment data sheets, plant flowsheets, $P \& I$ diagrams, and plant layout diagrams for the various site locations and hydrogen storage alternatives. Flowsheets 018-P-AFS-001-E and 018-P-AFS-002-E give a general view of the plant and of the utilities. In the P\&I diagrams for the various units, utilities inlet and outlet lines are indicated by guide numbers. The guide number list appears in data sheet 018-P-BDZ-002.

\section{2 .1 Section $100-2-\mathrm{MW} / 20-\mathrm{MWh} \mathrm{H}_{2} / \mathrm{Cl}_{2}$ Cell Module}

\subsubsection{1. $\mathrm{H}_{2} / \mathrm{Cl}_{2}$ System (see P\&I No. 018-P-API-101-C).}

The proposed configuration is based on the concept of a series of ten 2-MW/20-MWh modular units, for a total energy storage of $200 \mathrm{MWh}$. Each module consists of a cell (EL-101 A $\div \mathrm{J}) \dagger$, a foreign gas $\mathrm{K} .0$. drum (V-102 $A \div J) t$, and two vessels used as chlorine settlers and storage. The module is completed by an $\mathrm{HCl}$ circulation pump (P-101 $\mathrm{A} \div \mathrm{J}$ ) and by the pump $(P-102 \mathrm{~A} \div \mathrm{J})+$ for the addition of liquid chlorine during the cell discharge cycle (see module layout in Figure 4). This configuration is judged preferable to one having several cells in a single system of foreign gas disengagement, which would have allowed a lower number of K.O. drums (V-102), for the following reasons: (i) the difficulty of obtaining 20 to 24 in. diameter glasslined or P'l'F-lined pipes, and (ii) the higher operating flexibility of a module concept in case of failures, and the reduced number of valves.

The 2-MW/20-MWh module is a unit that can be completely segregated from the others and subjected to maintenance while the plant is on stream. Within the module, however, no equipment can be isolated: all the equipment must be emptied and purged during maintenance of any component. Because of this, ODN minimizes the number of high cost valves and flanges which are possible sources of leakage. Each module is connected to the next only through the hydrogen header, the foreign gas purge header, the let-down header, and the utilities network.

Modules are installed in separate concrete rooms with acid-proof flooring, kept at slightly sub-atmospheric pressure by a blower. Before discharge to the atmosphere, the room air is washed in an alkali scrubber. The building's roof will be at least partially removable for erection and maintenance of

\footnotetext{
*All Annexes and flow sheets are on file at BNL.

TThe numbers refer to the flow diagrams on file at BNL.
} 
equipment. The $\mathrm{Cl}_{2} / \mathrm{HCl}$ storage and foreign gas K.O. drums will be provided with weight indicators to monitor the fluid level and indicate the need for makeup. The suggested materials of construction for all parts in contact with $\mathrm{HCl}$ and chlorine are tantalum and glass-lined carbon steel. The chlorine metering pump is a PTFE membrane pump.
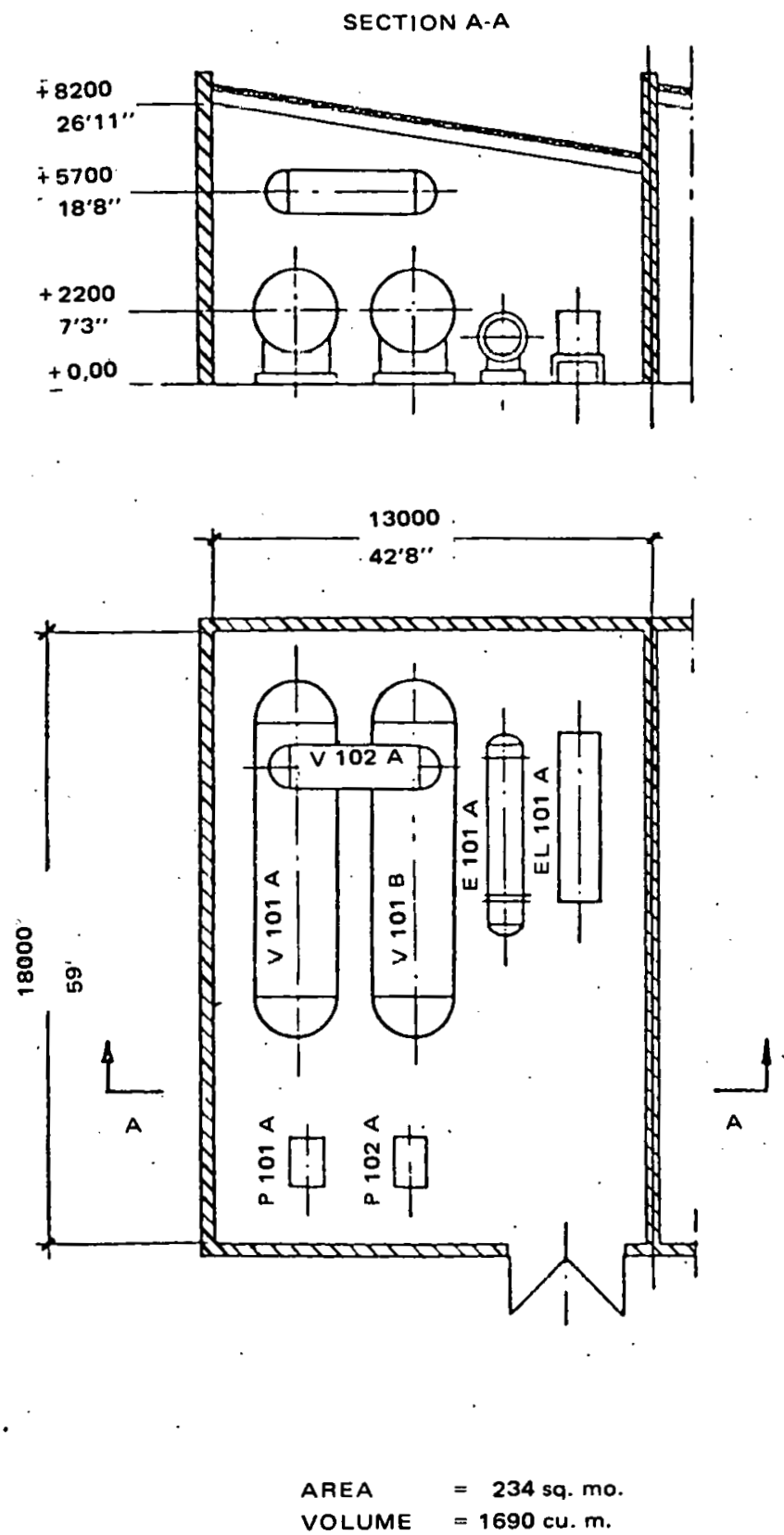

Figure 4. 2-MW/20-MWh $\mathrm{H}_{2} / \mathrm{Cl}_{2}$ Battery Module 


\subsubsection{2 $\mathrm{H}_{2} / \mathrm{Br}_{2}$ system.}

Because the lower operating pressure allows the use of larger vessels, the number of $\mathrm{HBr} / \mathrm{Br}_{2}$. storage tanks per module need be increased from two only to three. The high solubility of bromine suggests that a pump for metering $\mathrm{Br}_{2}$ injection during the cell's discharge cycle is not needed. Glass-lined carbon steel is surely an appropriate material for this type of service; tantalum needs to be further tested.

\subsubsection{Section 200 - Hydrogen Cleanup and Storage System (see P\&I No. 018-P-API-201/202)}

The cleanup. was designed to accommodate the production of hydrogen at 600 psia and to make hydrogen available during the discharge cycle at a constant pressure of 100 psia. The hydrogen is washed first with an alkali solution and then with softened water, the last traoos of caustin soda mist being removed by a high efficiency Brink-type mist eliminator. Caustic soda and water are fed to the system on a batch basis, their consumption depending on the actual amount of acid entrainment in the hydrogen leaving the cell.

Many alternatives for $\mathrm{H}_{2}$ storage have been considered, such as metal hydrides, high pressure storage with mechanical compression, and storage at the cell's production pressure without compression. Hydrides were not considered here because information on large-scale storage is lacking. Conventional pressure vessel $\mathrm{H}_{2}$ storage was evaluated from two different points of view: (i) minimization of investment cost, and (ii) minimization of parasitic power consumption and operating cost. Bechtel's solution, which uses $30 \mathrm{~T}-1$ st.eel cylinders to store hydrogen takes into account only the former and disregards other factors such as land requirements, piping complexity (il lias many block valves and safety relief devices), and the complexity of operating $\mathrm{H}_{2}$ compressors, which would increase the need for manual control.

ODN's technical experts suggested the use of 6 ( 7 in the $\mathrm{H}_{2} / \mathrm{Br}_{2}$ system) vertical carbon steel vessels operated at $600 \mathrm{psig}$, the operating pressure of the cell's hydrogen side during the charge period. Hydrogen is sent back to the cell during the discharge period, use being made of the possibility of operating the $\mathrm{H}_{2}$ side of the cell also at 100 psia while the $\mathrm{Cl}_{2}$ side is kept at a constant pressure of $400 \mathrm{psid}$. The choice of carbon steel is dictated by the difficulty of vessel fabrication with T-1 steel (suggested by Bechtel) which requires thermal treatment after manutacture to restore its good mechanical properties - a treatment giving rise to dimensional problems. The use of carbon steel raises the investment cost by about $\$ 1.2$ million (Bechtel's figure was $\$ 1.5$ million), i.e., by about 58 , but it has several advantages, the major one being a lowering of parasitic power consumption by about $17 \%$ at an industrial site and by $21 \%$ at a utility site. This means a lower total plant operating cost if the electric power wasted for fluid circulation is assumed to have some value. $(3 \mathrm{k} / \mathrm{kWh}$ in our work). If the wasted electric power has no value, this $\mathrm{H}_{2}$ storage option is of lees interest. 
Table 4 compares the economics of high and low pressure $\mathrm{H}_{2}$ storage for two money interest rates and two depreciation times. The use of low. pressure hydrogen storage also decreases land requirements, by about 22\% for the industrial site and $25 \%$ for the utility site. It also eliminates a few block and safety relief valves and involves no operating machinery; this is advantageous because every moving part is subject to wear and to malfunctioning.

\begin{tabular}{|c|c|c|c|c|c|}
\hline \multicolumn{6}{|c|}{$\begin{array}{c}\text { Cost of High Pressure (HP) and Low Pressure (LP) } \mathrm{H}_{2} \text { Storage } \\
\text { for a } 20-\mathrm{MW} / 200-\mathrm{MWh} \mathrm{H}_{2} / \mathrm{Cl}_{2} \text { system at an Industrial Site } \\
\text { (Price of stored energy }=3 \mathrm{k} / \mathrm{kWh})\end{array}$} \\
\hline \multirow{3}{*}{$\begin{array}{l}\text { Depre- } \\
\text { ciation } \\
\text { time, yr }\end{array}$} & \multirow[b]{3}{*}{ Cost item } & \multicolumn{4}{|c|}{ Yearly costs, $10^{3} \$$} \\
\hline & & \multicolumn{2}{|c|}{$68 / y x$ interest } & \multicolumn{2}{|c|}{$8 \% / y x$ interest } \\
\hline & & HP storage & LP storage & HP storage & LP storage \\
\hline \multirow[t]{3}{*}{10} & Operating cost & $2,628.9$ & $2,571.7$ & $2,628.9$ & $2,571.7$ \\
\hline & $\begin{array}{l}\text { Financial charges } \\
\text { Total cost } \\
\text { Delivered energy }\end{array}$ & $\begin{array}{l}3,058.6 \\
5,687.5\end{array}$ & $\begin{array}{l}3,221.8 \\
5,793.5\end{array}$ & $\begin{array}{l}3,351.0 \\
5,979.9\end{array}$ & $\begin{array}{l}3,529.8 \\
6,101.5\end{array}$ \\
\hline & cost, $\phi / k W h$ & 9.63 & 9.5 & 10.13 & 10.0 \\
\hline \multirow[t]{4}{*}{20} & Operating cost & $2,628.9$ & 2.571 .7 & $2,628.9$ & $2,571.7$ \\
\hline & Financial charges & $1,957.0$ & $2,061.0$ & $2,294.0$ & $2,416.4$ \\
\hline & $\begin{array}{c}\text { Total cost } \\
\text { Delivered energy }\end{array}$ & $4,585.9$ & $4,632.7$ & $4,922.9$ & $4,988.1$ \\
\hline & cost, $\phi / \mathrm{kWh}$ & 7.77 & 7.6 & 8.34 & 8.18 \\
\hline
\end{tabular}

\subsubsection{Section 1000 - Module's Let-down (see P\&I No. 018-P-API-100I)}

The let-down system is designed to be capable of removing quickly in liquid form, most of the chlorine and $\mathrm{HCl}$ stored in the modules to minimize leakage and to empty a module in the simplest way for mainitenance. The let-down vessels normally operate at the $\mathrm{Cl}_{2} / \mathrm{HCl}$ or $\mathrm{Br} 2 / \mathrm{HBr}$ storage pressure and are vented to the blow-down both by process pump p-101 and by compressed air injected at the top of the module; this allows quick operation even if p-lol is out of order or the electricity has failed. Transfer time can be as low as desired, but a reasonable value is 10 to $15 \mathrm{~min}$. A highex transfer rate would involve an unacceptable increase in the size of compressed-air lines and the let-down system.

After a malfunctioning module is repaired, liquid is transferred to it by compressed air, and the let-down system is ready for any new routine maintenance or emergency situation. 


\subsubsection{Section 4800 - Blow-down Facilities (P\&I No. 018-P-APU-4801)}

All vent gases are collected and treated in a blow-down system before venting to the atmosphere; this prevents air pollution under both normal operating and emergency conditions. Moreover, the blow-down system is designed to accept the joint occurrence of two emergencies, module failure and electric power failure. It is divided into three subunits:

A. A clean-up tower (C-4801) for the foreign gas from the cells and $\mathrm{Cl}_{2} / \mathrm{HCl}$ storage purge air.

B. An emergency hydrogen emission stack ( $\mathrm{CH}-4801)$ (located in the unit 200 area).

C. A module building ventilation-air cleanup (C-4802).

Subunit A. Tower C-4801 was designed to recelve foreign gas from cell and module purge air in an emergency. It was also checked for other situations in which some delay in resolution is acceptable. Three different streams may be fed to tower C-4801:

foreign gas, during normal operation;

purge air, during a module emergency or maintenance;

chlorine, only when the system must be shut down.

Disposal of chlorine due to purge or to module depressurization is mancontrolled to avoid overloading of the absorption system and chlorine emission to the atmosphere. The unit operates continuously and automatically both in normal operation and in case of electric power failure because it has a backup electric power generator driven by a diesel engine (MV-4801). Moreover, all electric motors are reaccelerated to avoid shutoff by short electric power failures.

Subunit B. The hydrogen from all the vents is collected and discharged to the atmosphere, safely through a suitable seal pot and stack ( $\mathrm{CH}-4801)$. This avoids any danger due to explosive mixtures.

Subunit C. This subunit provides for cullection of possible leakages from modules and minimization of pollution. Adequate analyzers will.monitor for air contamination in the module rooms. Building ventilation is provided by a tail-blower, and toxic gas abatement is achieved by an alkali washing tower. This subunit, like subunit $\ddot{A}$, has a backup electric power sourae.

\subsubsection{Other sections (see flow-sheet No. 018-P-AFS-002-E)}

The plant includes other sections, listed in Annex 1 (on file at BNL), which have not yet been fully designed. The hot water system will be designed to damp peak parasitic demand by means of heat accumulation and reuse. Within these utility units, ODN suggests a high pressure compressed-air reservoir large enough to empty a module and purge it for a reasonable time (4 to 5 hours). 


\section{SAFETY FEATURES}

The main hazard of this type of installation is the possible emission of toxic liquid which, at atmospheric pressure, forms a cloud that might damage the surrounding area. Another hazard is the possibility of a hydrogen explosion, but this is minimal, and the damage would be confined to the plant area. Safety analysis was done on two main aspects: (i) the impact of site location. on required safety measures, and (ii) the safety of plant operation under normal and emergency conditions.

\subsection{Impact of Site Location}

With regard to safety (as stated in Table 3, Section 4.1), industrial and utility sites are similar. There are people in the neighborhood who are not trained to face any emergency and may not be warned in time. This means that the plant must have the highest degree of safety and all precautionary measures should be taken. At a remote site all the people potentially exposed to a toxic gas cloud are employees well trained to face such an emergency, and the absence of other people may allow a lower degree of safety. For example, single modules may not need to be put into closed buildings. Because the industrial and utility sites had very few differences in safety conditions, ODN treated them as identical in its safety analysis.

\subsection{Safety in Plant Operation}

The analysis of plant safety was divided into two parts: safety in normal operation and safety during emergencies. Obviously the plant must be safe in an emergency, but it must also be made intrinsically safe to minimize the possibility of failure and of emergencies arising.

\subsubsection{Safety Under Normal Operating Conditions}

Some of the design features assuring intrinsically safe operation of this system are outlined below, and all of the safety features are summarized in Table 5 (at the end of section 5.2.1).

Cell and chlorine storage design pressure. The design pressure is about $50 \%$ higher than the normal operating pressure; this gives a good allowance in case of an emergency (usual design practice requires only a $10 \%$ margin).

Chlorine storage. The glass coating in the storage tanks is made with 5 layers for a total thickness of $1.5 \mathrm{~mm}$. The layers are divided into two groups: base coating and 0.7-mm-thick corrosion-resistant coating. Every layer is tested electrically at a maximum voltage of $15,000 \mathrm{~V}$ (rather than the normal $12,000 \mathrm{~V})$ to detect any irregularities in the deposited coating. The glass coating corrosion rate is $<0.01 \mathrm{~mm} / \mathrm{yr}$, yielding a lifetime of about 60 to 70 yr. In the supplier's opinion, the probability of failure due to misoperation during installation is 0.1 to $0.2 \%$ for a well constructed tank.

Points of chlorine leakage. The number of flanges and valves was minimized mainly to reduce the number of gaskets that can fail and also to simplify operation. 
Material and equipment choice. All the materials used are recognized as fully satisfactory by many manufacturers, and are capable of withstanding the required working conditions of highly corrosive environment plus high pressure. The pump and heat exchanger on the chlorine side are of tantalum, and the pressure vessels and piping are of glass-lined carbon steel. PTFE is used in the diaphragm valves and for the membrane in the chlorine metering pump. The equipment chosen has already been installed in similar situations.

Chlorine/hydrochloric acid piping. All pipes are manufactured and tested in the same way as vessels. Connection sealing is achieved with a special type of gasket that has high elasticity and is smooth and nonporous so as to be gastight. Laboratory tests were carried out by a supplier on a number of these gaskets at a pressure of $125 \mathrm{~kg} / \mathrm{cm}^{2}$ with continuous internal pressure variations for more than four months. The gaskets showed no leakage.

Chlorine pump. Mechanical power is transmitted to the process fluid through a dnuble diaphragm and a hydraulic nontoxic fluld; this oyctem avoids any spillage of chlorine to the exterfor and also inoreases membrane lifetime bocause no mechanical part hits the Teflon surface. Membrane lifetime is about $10,000 \mathrm{hr}$. Any permeation of the process fluid into the hydraulic fluid is revealed by a special detector which alerts the operator before leakage to the environment occurs.

Pumps' mechanical seals. (A) Hydrochloric acid recirculation pumps are provided with a double mechanical seal flushed by an external pressurized fluid to avoid external chlorine leakage in case of mechanical seal failure. This can be done in two ways: (i) Use of softened water as the flushing agent, so that the fluid is not toxic; but in case of mechanical seal failure, stored hydrochloric acid may be diluted, which necessitates makeup of concentrated acid. (ii) Flushing the mechanical seal with $35 \% \mathrm{HCl}$, so that seal failure does not cause acid dilution; but (a) the flushing system (piping, drums, circulating pumps, etc.) must be made of a suitable material, and (b) the flushing liquid is toxic and is therefore a possible source of pollution. In either case, the flushing circulation pump can be provided with a self-flushed single mechanical seal.

(B) On the hydrogen side, the washing towers' circulation.pumps are magnetically driven pumps that have no point of leakage.

Purge and vent system. All the drains Alscharge into two separate closed sewers, one for acid drainage and the other for alkaline. The sewerage is vented to the atmosphere through the blow-down system, and in addition block valves are provided to prevent unattended operation. Vent emissions are collected, and all the purge gas is washed before discharge to the atmosphere.

Chlorine disposal. The chlorine present in the plant area can be eliminated in two ways: electrochemically with production of $\mathrm{HCl}$ solution, or by a controlled purge to the blow-down tower with production of a commercial solutius of sodium hyporhlorite. This avoids any problem of aqueous waste. 
Plant pre-commissioning and start-up. ODN considers a good pre-commissioning job to be the best protection against plant failure. The entire plant is checked and tested with nontoxic fluids by an experienced team of engineers and operators following a fully detailed control program. During start-up with a dangerous fluid the whole plant begins to run under the strict supervision of a large team of skilled technicians. Greater human effort at the very beginning ensures safer normal operation with fewer personnel during the following years.

Table 5

Safety Features Under Normal Operating Conditions

High safety factor: 508 (rather than the usual 10\%) over design pressure for celils and chlorine storage.

Minimum number of valves and flanges: minimizes points of potential leakage. Highly reliable materials: tantalum, glass-lined carbon steel, fluorocarbons; Equipment already tested in operation: more than 50 vessels similar to the chlorine storage tank have been in use for many years.

All equipment shop-tested under operating conditions.

Special design pumps: HCl pump has double mechanical seal and nontoxic flushing agent to, prevent exterior pour of toxic fluid; $\mathrm{Cl}_{2}$ pump has double $\mathrm{Tef-}$ Ion diaphragm with nontoxic hydraulic fluid within, plus detector/alarm system for damage to $\mathrm{Cl}_{2}$ side of diaphragm to preclude spillage to the environment.

- Purge and vent system: all material from vents and drains is collected and "discharged through a highly efficient waste purification system.

All automatic control valves are fail-safe: this precludes undesired operation. Data acquisition system: all operations are monitored by computer.

\subsubsection{Safety During Emergencies}

All the features incorporated to ensure safety in an emergency are summarized in Table 6 . Emergencies involving $\mathrm{H}_{2}$ or $\mathrm{Cl}_{2} / \mathrm{HCl}$ are different. $\mathrm{H}_{2}$ is classified as explosive in mixture with air but can be easily vented to the atmosphere through a proper stack that takes advantage of its high diffusivity. This means that safety can depend on automatic interlock (see block diagram 018-P-ABD-201-E) or safety relief valves. $\mathrm{Cl}_{2}$, however, is extremely toxic so that automatic relief is not permitted. $\mathrm{Cl}_{2}$ or $\mathrm{HCl}$ can be vented to the blow-down system only under manual control; hence no manual relief valve or automatic let-down system is provided. The interlocking system is passive, i.e., quiescent in case of failure, so that a skilled operator must decide what to do to restore operation. All the safety measures are listed below.

A. Interlocking system (see block diagram No. 018-P-ABD-101-E). A complete interlocking system is activated by any possible type of failure.

B. Module buildings. Every 2-MW/20-MWh module is enclosed in a single concrete building with acid-proof flooring which contains all the $\mathrm{Cl}_{2} / \mathrm{HCl}$ storage and circulation equipment. The building is kept at slightly negative pressure by a suitable ventilation system which collects any emitted chlorine in an alkali scrubber (C-4802). The ventilation system is designed on the general basis of low ventilation during normal operation, and strong air circulation in a single-module building in case of emergency. All the block valves and pump control facilities are outside the building so that in an emergency an operator need not enter the building to put the system on standby. 
The module is also provided with a sprinkler system activated by the high temperature storage tanks to prevent chlorine evaporation. The building floor drain is segregated from the sewer by a seal pot.

C. Let-down. ODN considers the safest way of minimizing leakage in the modules to be quick transfer (in about $15 \mathrm{~min}$ ) of all the liquid contained in the storage, piping, cell, and heat exchanger to other empty pressurized vessels. Transfer is made via the process pump ( $P-101)$ and/or by pumping the liquid with compressed air. The transfer rate is subject to human control to match the blow-down scrubber efficiency. The operator must be well aware of the blow-down system performance so that he can modulate the air pressure to avoid any chlorine emission. The let-down system is designed to accommodate one module emergency and simultaneous electric power failure. The compressedair system reservoir is sufficient to empty and purge a module.

D. Blow-down system. The blow-down towers are always on stream. All circulation pumps, chilling equipment, fresh soda feeder, and blowers are driven by an electric power network having an alternative power source such as a diesel engine electric generator. The vent line to the atmosphere contains a continuous chlorine analyzer.

E. Glass coating failure. Any defect in the glass coating of vessels and pipes is detected by an automatic instrument, on the basis of the different electrical conductivities of the glass coating and the carbon steel. Any hole in the coating, even the tiniest, closes an electric circuit and rings an alarm on the control board. This means that failure can be detected at the earliest stage, as soon as metal corrosion starts.

Table 6

Safety Features Under Emergency Conditions

Interlocking system: all equipment is automatically put into a safe condition in case of failure.

Modularization: the ten-module design greatly decreases the possibility of leakage.

Chlorine storage vessel failure prealarm: an automatic detector in each vessel that signals even the tiniest failure of the glass ining allows prevention of corrosion before it gets started.

Self-contained: each module is in a closed building with negative pressure, and air is discharged through a washing system.

Let-down system: all the stored liquid $\mathrm{Cl}_{2} / \mathrm{HCl}$ is transferred in liquid form by means of compressed air.

Blow-down system: designed to run continuously and provided with spare equipment for use in case of component failure or loss of electricity.

Electric power failure: the plant was designed with the assumption (not usually made) that power failure could occur simultaneously with any other failure; all emergency services are provided, with electricity generated by a diesel engine and compressed air from high pressure storage. 


\subsection{Emission Limits}

The emission limits for the chemicals used are given below as timeweighted average limits (TWA) and short-term exposure limits (STEL). All data are from the American Conference of Governmental Industrial Hygienists (ACGIH) (1977).

\begin{tabular}{|c|c|c|c|c|}
\hline & \multicolumn{2}{|c|}{ TWA } & \multicolumn{2}{|c|}{ STEL } \\
\hline & ppm & $\mathrm{mg} / \mathrm{m}^{3}$ & ppm & $\mathrm{mg} / \mathrm{m}^{3}$ \\
\hline $\mathrm{Br}_{2}$ & 0.1 & 0.7 & 0.3 & 2 \\
\hline $\mathrm{Cl}_{2}$ & 1 & 3 & 3 & 9 \\
\hline $\mathrm{HBr}$ & 3 & 10 & - & - \\
\hline $\mathrm{HCl}$ & 5 & 7 & - & - \\
\hline
\end{tabular}

\section{PARASITIC POWER ANALYSIS AND OVERALL ELECTRIC EFFICIENCY}

\section{$6.1 \mathrm{H}_{2} / \mathrm{Cl}_{2}$ System}

A detailed analysis of the energy consumption due to fluid circulation and to the cell's thermal conditioning was done on the basis of the plant configuration indicated in Section 4 for the three plant locations and for both $\mathrm{H}_{2}$ storage concepts. Table 7 lists all the various parasitic energy consumptions incluaing those for $\mathrm{H}_{2}$ storage alternative, the electric power consumption is lower because of the absence of the compressor's consumption.

Overall electric efficiency for the $\mathrm{H}_{2} / \mathrm{Cl}_{2}$ systern was calculated for both storage alternatives (Table 8 ). Electrochemical and rectifier/inverter losses are taken from Bechtel's final report, but the opinion at ODN is that the problem of dc-to-ac conversion is not yet solved and therefore the figures given may represent a goal but are far from. real with the current. state of the art. Till now, at least in Europe, this problem has been studied only in special cases that are not applicable here.

\section{$6.2 \mathrm{H}_{2} / \mathrm{Br}_{2}$ System}

Parasitic consumptions were evaluated only for the utility site, with low pressure $\mathrm{H}_{2}$ storage (Table 9). Electric-to-electric efficiency was calculated for the utility site (Table 10). Voltaic and Coulombic losses are from BNL data. Comparison with the $\mathrm{H}_{2} / \mathrm{Cl}_{2}$ system indicates that the $\mathrm{H}_{2} / \mathrm{Br}_{2}$ system is more efficient:

$\begin{array}{lcc}\text { Parasitic consumption, } & \frac{\mathrm{Cl}_{2} \text { system }}{7.46} & \frac{\mathrm{Br}_{2} \text { system }}{4.12} \\ \begin{array}{l}\text { Overall efficiency, } 8 \\ \frac{60.6}{6}\end{array} & 66.6 & 69.83\end{array}$

Note, however, that these conclusions are valid only if the assumptions indicated in section 3.2 are valid. 
Table 7

20-MW/200-MWh $\mathrm{H}_{2} / \mathrm{Cl}_{2}$ System Parasitic Consumptions

Case A. Industrial site

Case C. Remote Site

Filectric Power
Case B. Utility site

Electric Power

Charge Discharge

Cycle Cycle standby

$\mathrm{kW} \quad \mathrm{kW} \quad \mathrm{kW}$

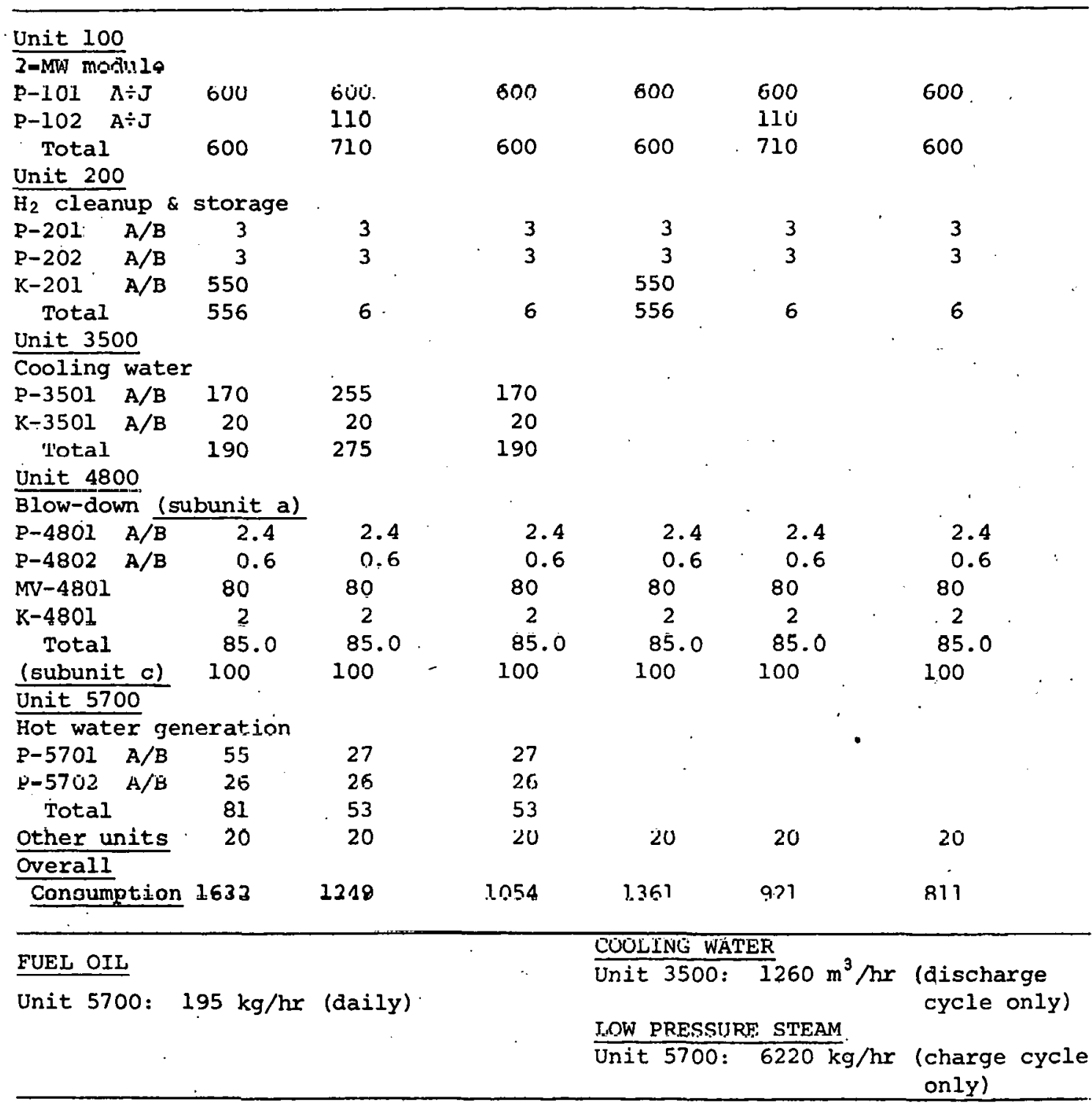


Table 8

Overall Electric Efficiency of $20-\mathrm{MW} / 200-\mathrm{MWh} \mathrm{H}_{2} / \mathrm{Cl}_{2}$ system (Based on daily cycle of $10 \mathrm{hr}$ charge $+10 \mathrm{hr}$ charge $+4 \mathrm{hr}$ standby)

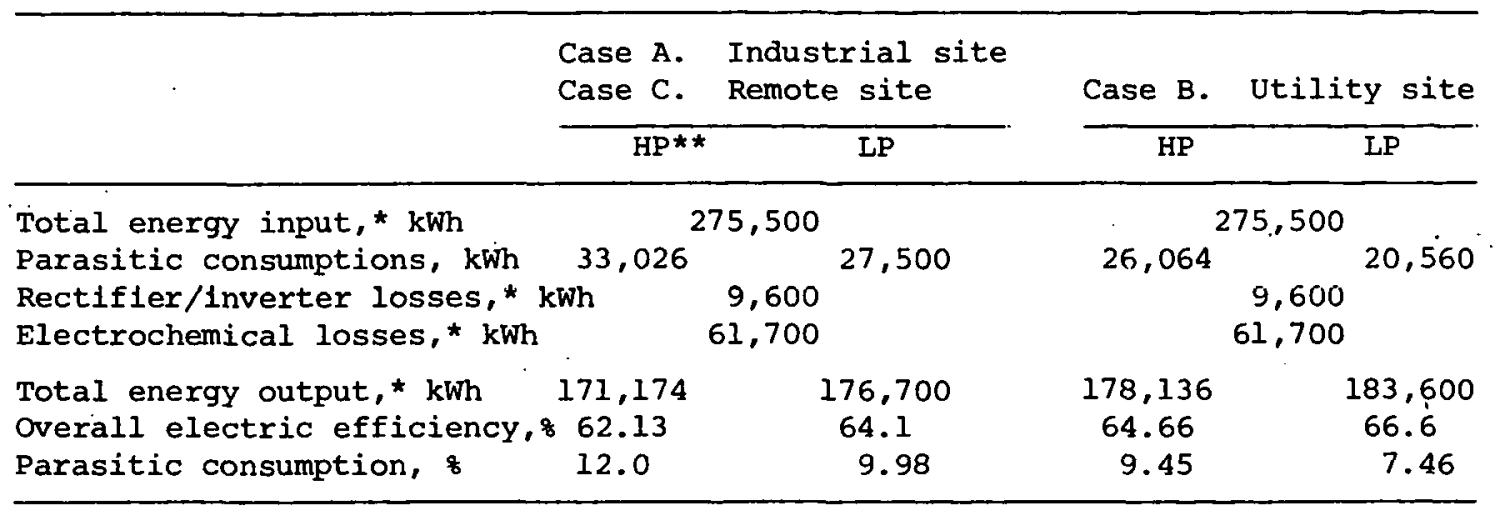

*Data from Bechtel final report.

${ }^{*} \mathrm{HP}=$ high pressure $\mathrm{H}_{2}$ storage $(2000 \mathrm{psig}) ; \mathrm{LP}=$ low pressure $\mathrm{H}_{2}$ storage (600 psia).

\section{Table 9}

20-MW/200-MWh $\mathrm{H}_{2} / \mathrm{Br}_{2}$ System Parasitic Consumptions (Utility site; low pressure hydrogen storage)

\begin{tabular}{ccrr}
\hline & Charge & Discharge & Standby \\
\hline Electric power, $\mathrm{kW}$ & & & \\
HBr/Br 2 circulation & 300 & 300 & 300 \\
Hydrogen cleanup & 6 & 6 & 6 \\
Blow-down facilities & 185 & 185 & 185 \\
Total & 491 & 491 & 491 \\
Cooling water, $\mathrm{m}^{3} / \mathrm{hr}$ & - & 3480 & - \\
\hline
\end{tabular}

Table 10

20-MW/200-MWh $\mathrm{H}_{2} / \mathrm{Br}_{2}$ system Electric-to-Electric Efficiency (Utility site; low pressure hydrogen storage; $10 \mathrm{hr}$ charge $+10 \mathrm{hr}$ discharge $+4 \mathrm{hr}$ standby)

\begin{tabular}{lcc}
\hline & Energy, MWH & Efficiency, $\%$ \\
\hline Charge input & 286.4 & - \\
Parasitic losses & 11.8 & 4.12 \\
Rectifier/inverter losses & 61.8 & 77.5 \\
Electrochemical losses & 12.8 & 94.0 \\
Energy output & 200 & - \\
Overall efficiency & - & 69.83 \\
\hline
\end{tabular}




\section{PLANT COST ESTIMATE}

All the plant cost estimates were made without taking into account any land costs because these costs were not known. Aside from land costs, the requirements of the different site locations have minimal impact on plant cost.

\section{$7.1 \quad 20-\mathrm{MW} / 200-\mathrm{MWh} \mathrm{H}_{2} / \mathrm{Cl}_{2}$ System}

The cost of $\mathrm{a} \mathrm{H}_{2} / \mathrm{Cl}_{2}$ plant was evaluated in detail. For the low pressure hydrogen storage plant the cost is as follows:

\begin{tabular}{ll}
\multicolumn{1}{c}{ Site } & $10^{6} \$$ \\
industrial & 23.69 \\
utiifty & 23.12 \\
rcmotc. & 23.38
\end{tabular}

The above figures are based on a detalled analysis of the various cost itcms. Most of the equipment costs are from suppliers' quotations and other data are from oDN files.

Table 11 summarizes the cost analysis for the case of high pressure $\mathrm{H}_{2}$ storage, with various site locations. Following a BNI suggestion, the plant costs were separated into those related to the power installed and those related to the energy storage capacity. Table 12 summarizes the results for the utility site case with low pressure $\mathrm{H}_{2}$ storage.

\subsection{0-MW/200-MWH $\mathrm{H}_{2} / \mathrm{Br}_{2}$ System}

The costs of this alternative were evaluated only approximately, in terms of differences from those of the $\mathrm{H}_{2} / \mathrm{Cl}_{2}$ system. This was done because the lack of knowledge of bromine and/or $\mathrm{HBr}$ behavior with cominon materlals makes it difficult for suppliers to give accurate price quotations. The main differences are listed below.

Unit 100. Ten 2-MW/20-MWh modules. The cost of the halogen/acid vessels is less by about $\$ 1.7$ million. Omission of the Br2 pump can save as much as \$U. 45 million:

Unit 200. $\mathrm{H}_{2}$ cleanup and low pressure storage. The cleanup is essentlally the same, but the storage vessel cost.is higher by $\$ 0.8$ million.

Unit 1100: Lct-down. The number of vesael.s is groatcr, but the cost of the equipment is less by about $\$ 0.2$ million because of the lower pressure.

Unit 5700. Hot water. Since the $\mathrm{H}_{2} / \mathrm{Br}$ ? system does not reed any heat input, being isothermal on charge, omission of this unit lowers the cost of the general utilities by about $\$ 75,000$. 
Table 11

Cost $\left(10^{3} \$\right)$ of $20-\mathrm{MW} / 200-\mathrm{MWh} \mathrm{H}_{2} \mathrm{Cl}_{2}$ Battery With High Pressure $\mathrm{H}_{2}$ Storage

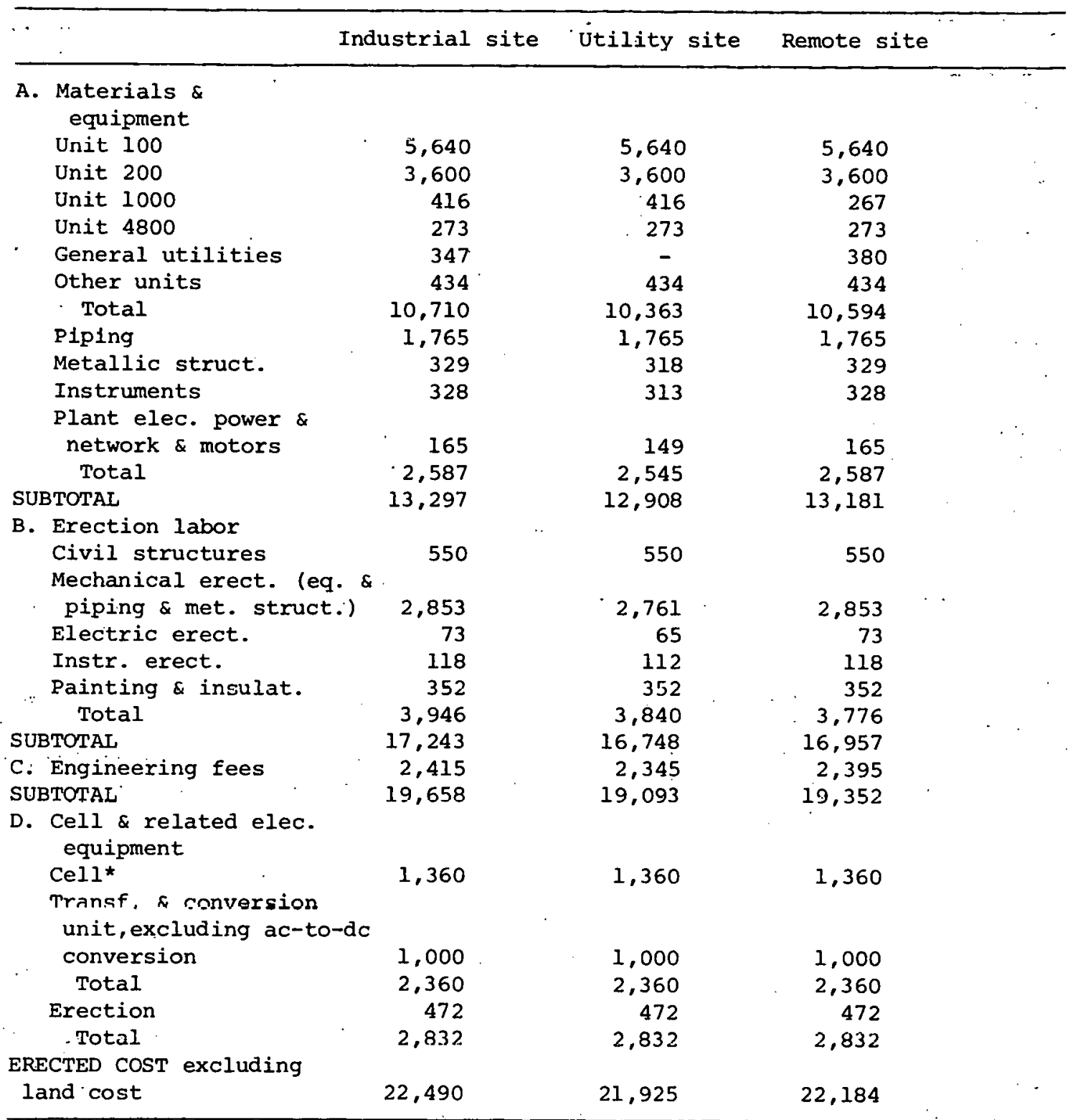

*ODN has assumed the value of $68 \mathrm{~s} / \mathrm{kW}$ indicated in Bechtel's final report pg. 9. 
Table 12

Cost of $20-\mathrm{MW} / 200-\mathrm{MWh} \mathrm{H}_{2} / \mathrm{Cl}_{2}$ system Separated Into

Power and Energy Costs $\left(10^{3} \$\right)$

(Utility site; low pressure $\mathrm{H}_{2}$ storage)

\begin{tabular}{|c|c|c|c|c|c|c|}
\hline & 1 & . & Power & Energy & & \\
\hline Ten 2-MW/2OMWh modu & les & & $v^{\prime}$ & & & . \\
\hline Equipment & & ' & 2,343 & 3,297 & & \\
\hline Piping & . & . & 465 & 465 & & \\
\hline $\mathrm{H}_{2}$ Cleanup & & & & & & \\
\hline Equipment : & & . & 96 & 4,704 & & . \\
\hline Piping & & & 235 & 235 & & \\
\hline \multicolumn{7}{|c|}{ Let-down and blow-down } \\
\hline Equipment & & & - & 689 & & \\
\hline Piping & & & - & 114 & & \\
\hline Uther units & & & .685 & - & & \\
\hline Structures & & ' & 91 & 227 & & \\
\hline Instruments & & & 157 & 156 & & \\
\hline Electric network & & & 149 & - & & \\
\hline Electric labor & . & - & 1,390 & 3.050 & & \\
\hline Engineering fees & & & 709 & 1,636 & & \\
\hline Cel1 and conversion & & & 2,832 & - & & \\
\hline Total & & & 9,152 & 14,573 & & \\
\hline Unit cost & & & $457.6 \$ / \mathrm{kW}$ & 72.865 & $\$ / \mathbf{k W h}$ & \\
\hline
\end{tabular}

These rough approximations indicate that the total plant cost with bromine would be about $\$ 1.7$ million less than with chlorine. This is a tentative figure because it does not take into account the higher cost of the $\mathrm{HBr}$ circulation pump, which could raise the module cost by as much as $10 \%$, or any change in the cost of the electrolyzer and the conversion unit. With the assumptions used, the bromine plant cost is about $\$ 22.0$ million.

\subsection{Plant Capacity Impact}

On the basis of the cost estimate in section 7.1 , the cost trend with increasing storage capacity was determined (Figure 5). The estimate was based on the plant design developed for the 200-MWh size, assuming the same system of energy for utility demand peak-shaving. This is not very realistic for such items as the hot water accumulator, but a more detailed case by case analysis was beyond the scope of this ODN study. The figures could be improved by better evaluation of the charge-discharge cycle length. A different cycle, for example a battery coupled to a solar power source running only in the daytime or to a wind generator, might reduce annual utility consumptions and or personnel requirements and thus reduce the delivered energy cost. 


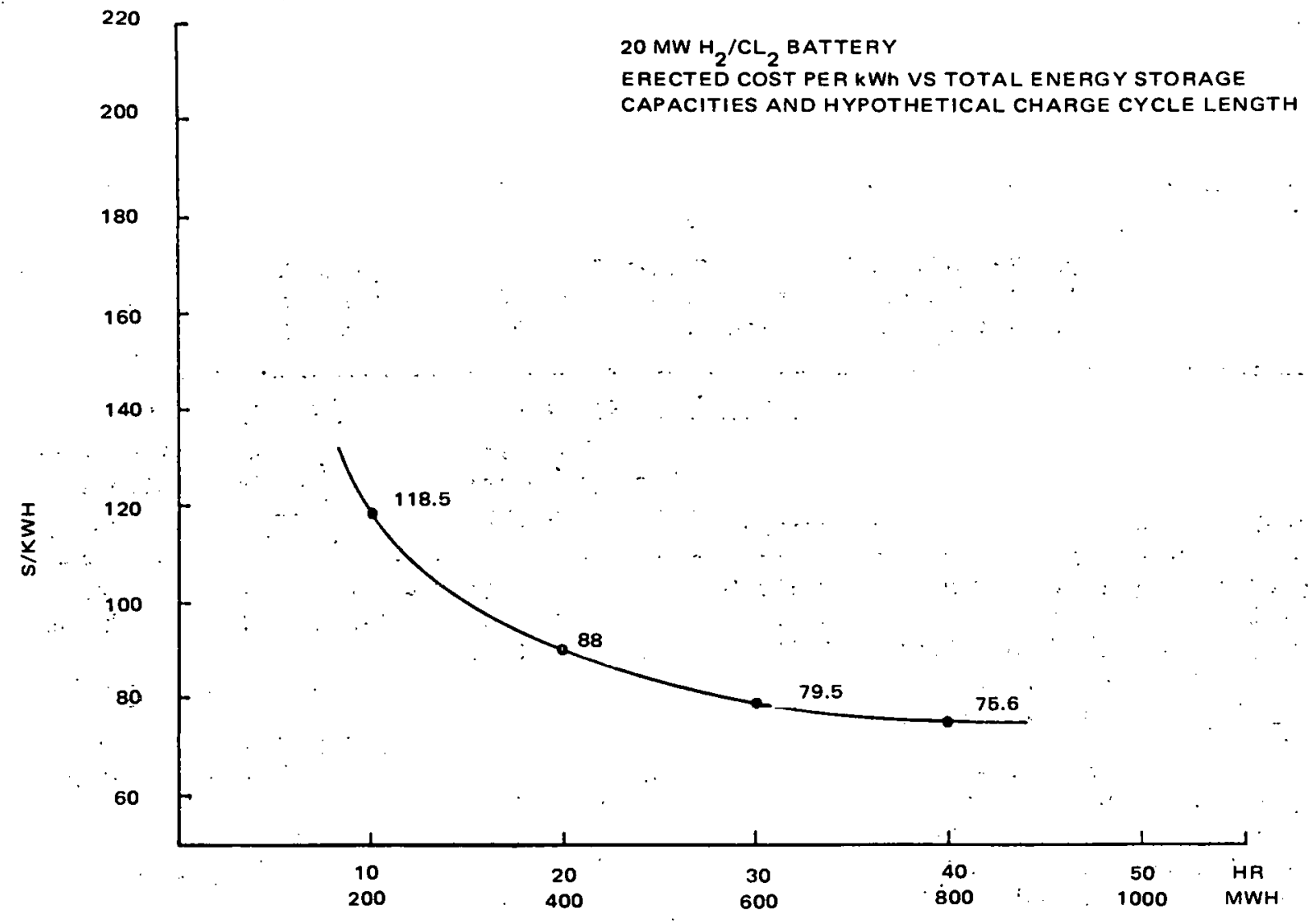

Figure 5 .

\section{DELIVERED ENERGY COST}

The last step in the study of the $\mathrm{H}_{2} / \mathrm{Cl}_{2}$ energy storage system was to define the cost of the energy delivered by it. This presented many problems. The first was to determine the cost of the electric power absorbed by the plant for parasitic consumption and to decide whether to credit this at the normal commercial price or to consider it free of charge because it has no other market. This problem was approached by using different costs with different electric power prices. The other problem not easily soluble with the data available to ODN was to find accurate values for the fixed costs, i.e., those for financing, maintenance, manpower, etc. These depend largely on geographical and political considerations and could be only roughly estimated by ODN. Table 13 shows delivered energy cost as a function of electricity cost and of site location. The cost of the energy stored with a $\mathrm{H}_{2} / \mathrm{Cl}_{2}$ system ranges from 5.9 to $7.6 \mathrm{k} / \mathrm{kWh}$ at an industrial site and from 5.78 to $7.28 \mathrm{k} / \mathrm{kWh}$ at a utility site. These figures are for low pressure $\mathrm{H}_{2}$ storage, the alternative, recommended by ODN. They are compared with those for high pressure $\mathrm{H}_{2}$ storage in Table 14 . The cost is slightly higher (by $0.16 \mathrm{k} / \mathrm{kWh}$ ) with the $\mathrm{H}_{2}$ compressor. 
Table 13

20-MW/2O0-MWh $\mathrm{H}_{2} / \mathrm{Cl}_{2}$ System Delivered Energy Cost

With Different Electricity Costs and site Locations

(Low pressure $\mathrm{H}_{2}$ storage; daily cycle $\times 345 \mathrm{~d} / \mathrm{yr}$ )

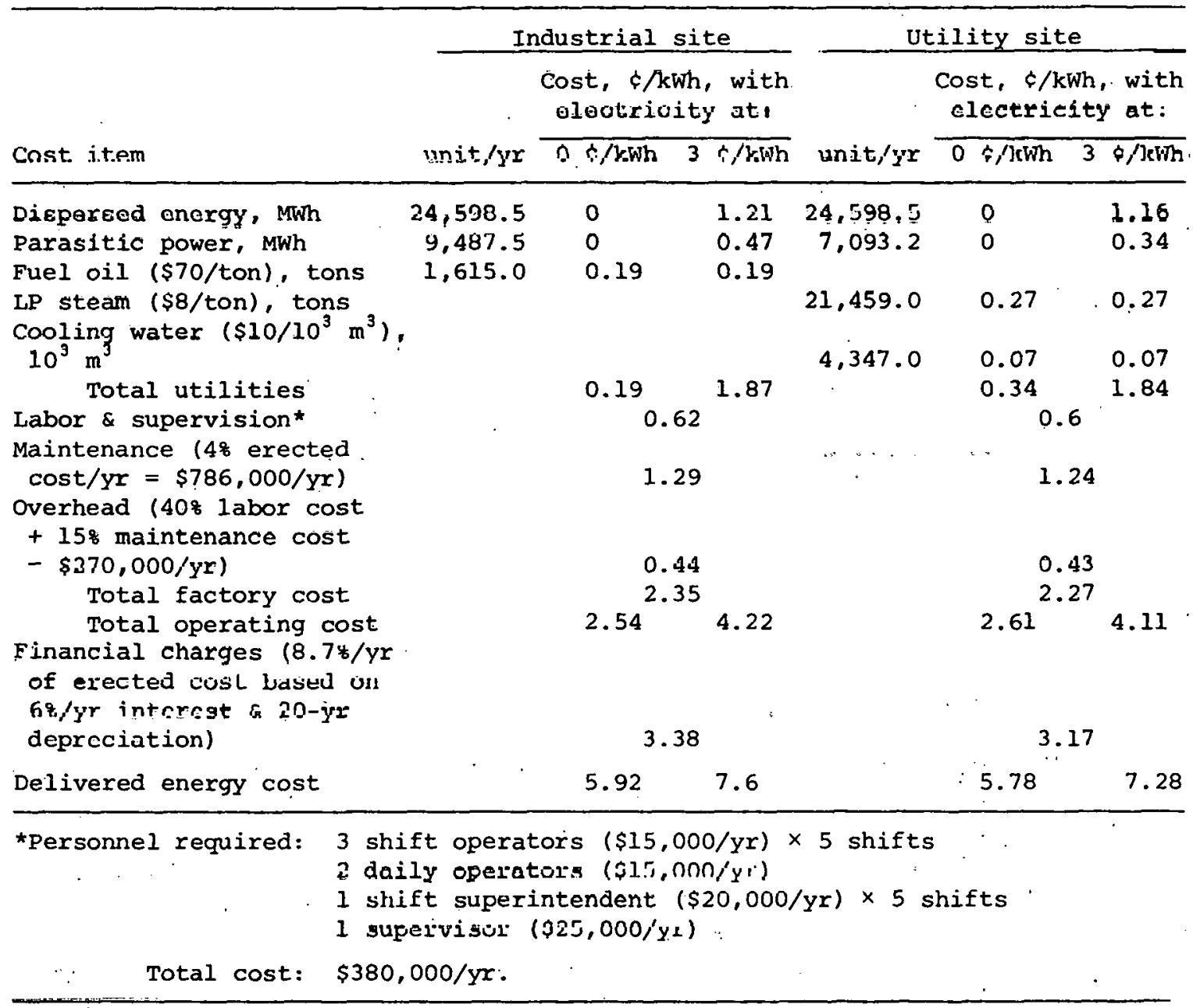




\begin{tabular}{|c|c|c|}
\hline \multicolumn{3}{|c|}{$\begin{array}{l}\text { 20-MW/200-MWh } \mathrm{H}_{2} / \mathrm{Cl}_{2} \text { System Energy Cost with } \\
\text { High Pressure (HP) and Low Pressure (LP) } \mathrm{H}_{2} \text { Storage } \\
\text { (Industrial site; electricity cost }=3 \mathrm{c} / \mathrm{kWh} \text { ) }\end{array}$} \\
\hline Cost item & LP & $\mathrm{HP}$ \\
\hline \multicolumn{3}{|l|}{ Operating costs } \\
\hline Cell efficiency & 1.21 & 1.25 \\
\hline Parasitic losses & 0.47 & 0.58 \\
\hline Fuel oil & 0.19 & 0.19 \\
\hline Labor/supervision & 0.62 & 0.64 \\
\hline Maintenance & 1.29 & 1.33 \\
\hline Overhead & 0.44 & 0.46 \\
\hline Financial charges (8.78) & 3.38 & 3.31 \\
\hline Delivered energy cost $(\xi / \mathrm{kWh})$ & 7.60 & 7.76 \\
\hline
\end{tabular}

\section{ACKNOWLEDGMENTS}

We gratefully acknowledge the scientific and technical support given by the following persons and companies:

Brookhaven National Laboratory - Dr. J. McBreen, Mr. F. Salzano, Dr. S. Srinivasan, and Dr. Y. S. Yeo.

Clarkson College - Dr. D-T. Chin.

Vicarb S.A. (tantalum pump and heat exchanger) - Mr. De Petris, Mr. Fayol, and Mr. Palmeri.

Worthington S.p.A. (tantalum pump).

D.K.M. (chlorine membrane pump).

A.T.B. Brescia-Italy (heavy-wall hydrogen storage).

Pfaudler (glass-lined chlorine storage) - Ing. Martinello.

Iesco Engineering (ITT-Grinnel Teflon-lined diaphragm valve) -

Ing. Aimetti. 